\title{
Trade Friction and Chinese Innovation: A Case Study of the Semiconductor Industry
}

\author{
Al-Sayed, Rafif and Yang Jianhua \\ University of Science \& Technology Beijing (USTB), China
}

\begin{abstract}
Major Chinese innovative technologies still depend on imported foreign core technologies. This dependence could affect sustaining growth in technological innovation for the Chinese Hi-Tech industry, which is one of the areas that has been most affected by the recent US-China trade conflict. The research explores if there is an impact of tension in trade scene on innovation in core technologies from the perspective of Hi-Tech industry experts in China. The method used a combination of semi-structured interviews and questionnaires addressed to experts and managers in the Chinese Hi-Tech industry. The statistical analysis used regression analysis of the experts' answers where the findings propose a possible positive impact on endogenous innovation in the long term if it is combined with government policies that enhance

innovation and increase R\&D expenditures. The paper also highlighted the challenges that affect innovation in this industry and stresses the importance of the role of the entrepreneurial state that helped China to achieve breakthroughs in other domains. A case study of the semiconductor industry was analysed as a

far-reaching endeavor, taking into account the scale of the challenges and the way forward for this significant core technology on which all of China's Hi-Tech industries and exports depend.
\end{abstract} *Correspondence to Author: Al-Sayed Rafif

University of Science and Technology Beijing How to cite this article:

Al-Sayed Rafif and Yang Jianhua. Trade Friction and Chinese Innovation: A Case Study of the Semiconductor Industry. Global journal of Economics and Business Administration, 2020, 4:28.

Keywords: Global Trade Friction, Chinese Innovation, Endogenous Innovation, Chinese semiconductor industry, Made in China 2025.

\section{eScî̀Pub}

eSciPub LLC, Houston, TX USA. Website: https://escipub.com/ 


\section{Introduction}

China is considered today to be the world leader in manufacturing industries, whereby $(22 \%$ to $17.4 \%)$, China has overtaken the US in global manufacturing output. (MAPI, 2014). Its exports of manufactured products are also the largest in the world (IMF, 2018). With the new large scale investments provided through the Belt and Road (OBOR) initiative (State Council, 2013), combined with China's realization that it needs to move to higher value-added manufacturing industries, are expected to have a giant leap forward (Schwab, 2017). Nevertheless, to move from the objective of "Made in China" to that of "Created in China" is deemed to be a significant challenge for China. (State Council, 2015). To achieve this objective, China has put a new generation internet-based computing, and advanced services as the cornerstone of what the Chinese government is vigorously pursuing in its role as a catalyst of entrepreneurship and technological innovation through a set encouraging innovation policies. Its premise is that if China manages to innovate on the level of breakthrough and core technologies, it will be able to play a catalyst role for innovation-based development in both China and the global scene (Zhou et al. 2017).

However, Wübbeke et al. (2016) indicated that China still lags considerably behind most of the developed countries, when it comes to cutting edge technological innovation. Whereas China is a world leader in innovation related to customization and efficiency-driven archetypes, it still has not caught up with the advanced industrial countries in science and engineering innovation-based archetypes. The fulfillment of China's aspirations concerning the OBOR initiative would inevitably require that China breaks through the monopoly of high-end manufacturing and core technologies by developed countries (Wübbeke et al. 2016). Meanwhile, the rising trends of protectionism in the US and other western countries, combined with political mistrust of China's ambitious $\mathrm{Hi}$ Tech ambitions is gradually creating a new paradigm in Sino-western exchanges. This paper studies how experts in the Hi-Tech industry perceive a possible effect of the unstable global trade situation on China's concentrated effort to transform its economy into one based on innovation. It tries to investigate if the Increase in Science and Technology indicators, particularly the considerable expansion in R\&D expenditure and the focus on new product development, could be explained in the light of this tension (as viewed by the US) or friction (as viewed by China).

\section{Literature review}

Globalization and an ever more liberal world trade system can have a positive impact on technology diffusion if this is paralleled in the receiving country with a comprehensive indigenous innovation strategy, including governance and institutional structures, that is attuned to innovation, which has been plausibly documented in the literature (Fu, 2011). China was not late in issuing its National Medium and Long Term Program for Science and Technology Development (S\&T MLP) following its membership in the World Trade Organization and the issuing of its provincial patent promoting policies (2006-2020). The State Council of the People's Republic of China, unveiled the National Medium- and Long-Term Program for Science and Technology Development, also known as S\&T MLP. In this plan, the innovation trajectory for China was set, defined, and the main framework of the concept of 'indigenous innovation' was established (Fu \& Xiong, 2011; Liu et al. 2011). The development goals of the program included becoming an 'innovationoriented society' and ranking as one of the top five countries in the number of invention patents granted by 2020 .

The objectives laid out by the State Council within this program provide a clear illustration of China's desire to become a world power in innovation. Aiming at nurturing innovative activities, and harnessing all national efforts, China's State Intellectual Property Office's (SIPO) also launched the National Patent 
Development Strategy (2011-2020). To achieve the strategy's central goal of enhancing China's capacity to create patents, SIPO has stipulated several goals to improve the capacity of domestic patentees significantly (SIPO, 2017).

China's outstanding blueprint 'Made of China 2025 'was put forward as a national strategy designed to dramatically enhance competitiveness and the manufacturing industries through introducing and implementing cutting edge automation and process technologies. China's outstanding blueprint 'Made of China 2025' was put forward as a national strategy designed to dramatically enhance competitiveness and the manufacturing industries through introducing and implementing cutting edge automation and process technologies. In order for achieving higher added-values in manufacturing, the strategy focused on improving innovation, integrating technology and industry, consolidating the industrial base, promoting Chinese brand names, and adopting green manufacturing practices (Tong \& Wang, 2017). Additionally, "Internet + " is promoted in this strategy as a means to modernize traditional industries and further fuel its growth. The strategy calls for the introduction of a modern manufacturing ecosystem that will enable further development of e-commerce, industrial networks, and on-line banking, as well as extending the presence of Chinese Internet companies internationally. The action plan for this strategy set development targets and supporting measures in each manufacturing sector, which is believed to help establish higher manufacturing standards and industrial modes (State Council, 2015).

All this is expected to lead to a newly evolving manufacturing ecosystem that will dramatically change the conventionally perceived manufacturing system in China based on an open design and manufacturing platform that can positively impact innovation on a hitherto unprecedented scale in China (Butollo \& Luthje 2017).
A plethora of product design studios, technology incubators, rapid prototyping shops, and other manufacturing related services, all of which are interconnected and integrated within one vast ecosystem, are remarkably conducive to rapid-low-cost commercialization of new products( (Brown, 2017). The success of China's efforts to limit its dependence on foreign technology are eventually expected to transform China from a 'Big Industrial Economy' to a 'Powerful Industrial Economy' will depend mainly on its ability to enhance indigenous innovation and minimize the risks associated with it (Howell, 2015)

This novel environment can potentially lead to China becoming a world leader in open-source manufacturing, providing outsourced development and manufacturing services to manufacturers from around the world with a faster and less expensive development cycle to commercializing innovation. Even multinational companies from the industrialized world Could benefit from China's model for open-source manufacturing to accelerate releasing products into new markets and reduce costs. This, potentially, could be a dramatic development that would transform China into a world innovation hub. If China succeeds in achieving its objectives, the "China effect" on innovation may have a global impact, where manufacturing services in China are being increasingly sought by companies seeking low cost and rapid innovation. This is a transformative effect that brings agile and large-scale manufacturing to emerging markets, and helping to produce a large variety of new products and services to ever-expanding markets, where the criteria is better quality and lower prices. However, China depends on achieving this goal in importing the advanced core technologies, specially in the $\mathrm{Hi}$ Tech industries from other countries. In this context, Chinese technological innovation encounters a real challenge in terms of unstable trade relationships between countries. Could innovation sustainability be prone to the trade friction? A turning point in US-China trade 
relations was in 2018, where unprecedented levels of friction encountered these relations.

In the following section, S\&T innovation indicators in China will be reviewed in order to identify the sector and location where innovation is noticeably increasing. The analysis of the indicators will help to understand how the S\&T policy in China for enhancing innovation has been implemented effectively and if there are any changes in these indicators in recent years?

\section{S\&T Innovation Indicators}

Continuous and rapid technological changes characterize modern economies. Economic research in the past decades has confirmed that technological changes are the most significant drivers of growth in GDP over the long term for major developed countries such as the US, Japan, and Germany (Barro \& Sala-I-Martin, 2004; Romer, 1990). However, the acceleration of technological change in many sectors present essential problems for government activities in measuring innovation. Research on this issue has not established any linear relationship between the input of the innovation process and its output, where many variables can contribute to increasing the possibility of innovation performance and export activities ( $\mathrm{Fu}$ et al. 2011). Although traditional methods can be used to count certain inputs to the innovation process, the continuous change nature of the technology makes it difficult to measure the nature of innovation outcomes, as well as the characteristics of the given country's innovation ecosystem, or, as the case is in many countries, innovation ecosystems since innovation in many industries tends to cluster in certain geographic locations. According to Litan et al. (2011), developing metrics linking changes in inputs to changes in outputs and societal impacts using traditional methods is a challenging task.

However, careful analysis of innovation in S\&T indicators can provide decision makers with highly relevant information needed to make decisions related to China's innovation. Essentially, the conditions that had previously allowed China to be very successful in acquiring, imitating and assimilating foreign technologies so that it was able to enter into higher added value technological fields are to a large extent the same conditions required to allow it to become innovative, provided they are fine-tuned to deliver the required results (Yip \& McKern, 2014) Abrami et al. 2010). This includes the highly skilled human resources, the necessary organizational structures, and the infrastructural assets (Ceccagnoli et al. 2016). All these are prerequisites for the transformation of an economy into an innovation and knowledgecreation based economy - given that the finetuning process is implemented correctly, timely, and in a result-oriented way as it is shown in Figure 1 (Litan et al. 2011)

According to OECD (2015), the free flow of talent, information, and capital is the real engine powering global innovation. China competes with the US on the amount of money spent by corporates in "importing" R\&D. However, China depends far more than the US on innovation efforts of overseas based companies. Meanwhile, China continues to attract R\&D investments benefitting from its low development costs and overheads, centrality to the high growth Asian markets and proximity to key manufacturing sites. If immigration and trade policies in major industrial countries become more stringent and less welcoming for R\&D operations, China is expected to further benefit from increased innovation flows from overseascompanies. (OECD, 2015).

The assessment of innovation in a specific sector requires measuring key innovation process inputs such as R\&D expenditure and key innovation outputs such as new products or processes

are a crucial factor of consideration. R\&D is linked to innovation, while it has been argued that the linear model of innovation is not accurate (Kline and Rosenberg, 1986; Freeman, 1996). Actually, China's fast economic growth has been associated with active involvement in $R \& D$ activities (Boeing et al. 2016), where research has clearly indicated that the more 
Chinese firms adopting R\&D activities, the more likely it is that they will innovate (Litan et al. 2014; Anil et al. 2013).

For instance, some firms confirm this positive relationship, while some others found a negative relationship, specially when it does not have the complementary asset $R \& D$ becomes only costs (Freel and Robson, 2004). According to the Statistical Yearbook 2017, China has witnessed rapid increases in both the total amount of R\&D expenditure and its ratio to GDP, with industrial manufacturing companies accounting for more than $70 \%$ of the R\&D expenditure.

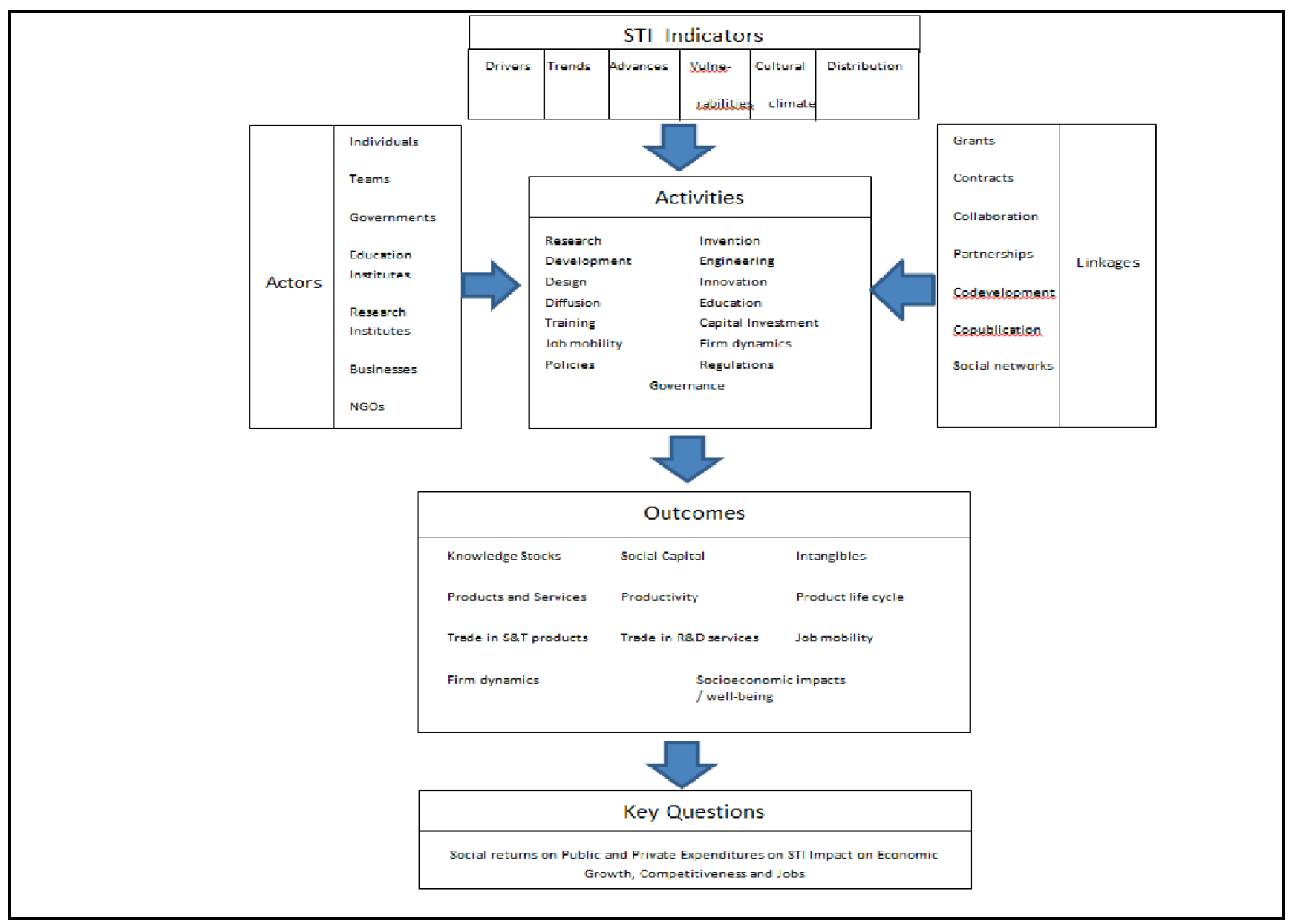

Figure 1: A Policy-Driven framework for STI innovation. Adopted from (Litan et al. 2014)

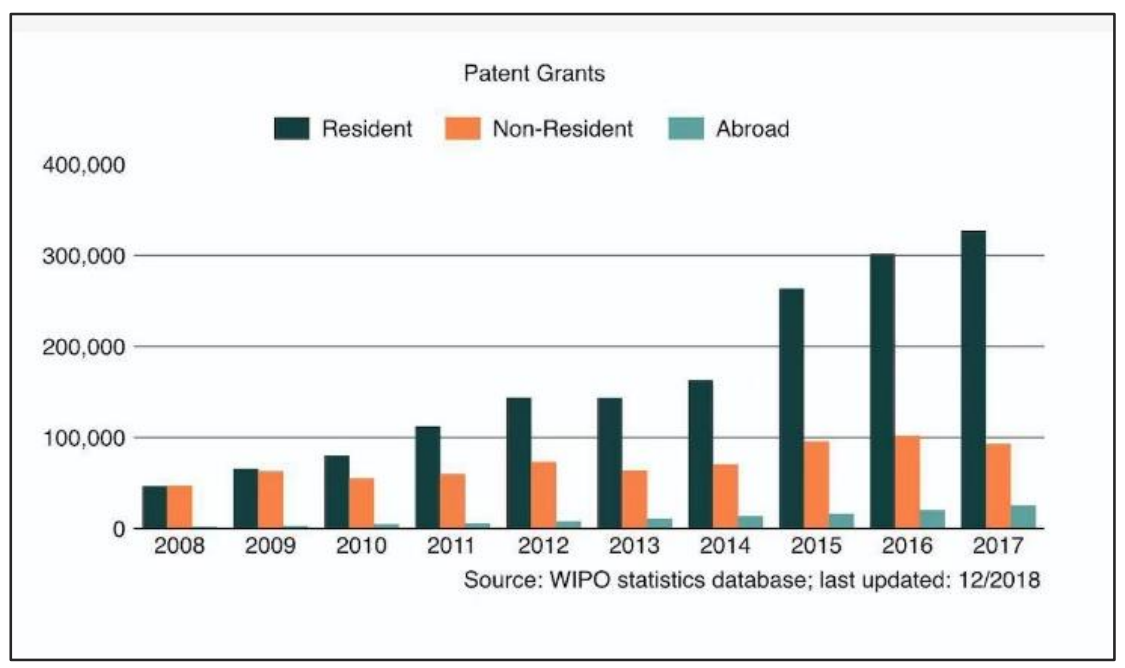

Figure 2: The Increase in the number of granted patents in China over nine years

GJEBA: https://escipub.com/global-journal-of-economics-and-business-administration/ 
For example, between 2013 and 2014, China achieved an $11.1 \%$ increase in $R \& D$ expenditure by manufacturing enterprises with total sales revenues of more than 20 million yuan, which amounted to 925.43 billion yuan, which accounts for an $11.1 \%$ increase from 2013. China's innovation capabilities and expenditures between 2006-2018 have remarkably increased, as illustrated in Figure 3 shows China's growing expenditure on Hi-Tech R\&D, where the increment in the amount of expenditure on $\mathrm{Hi}$ Tech R\&D, was around ten times between 2006 and 2017. Most noticeable here is the significant increase in R\&D expenditures, in 2016-2017, where Hi-Tech increased from 291.57 Billion yuan in 2016 to 541 Billion yuan in 2018 .

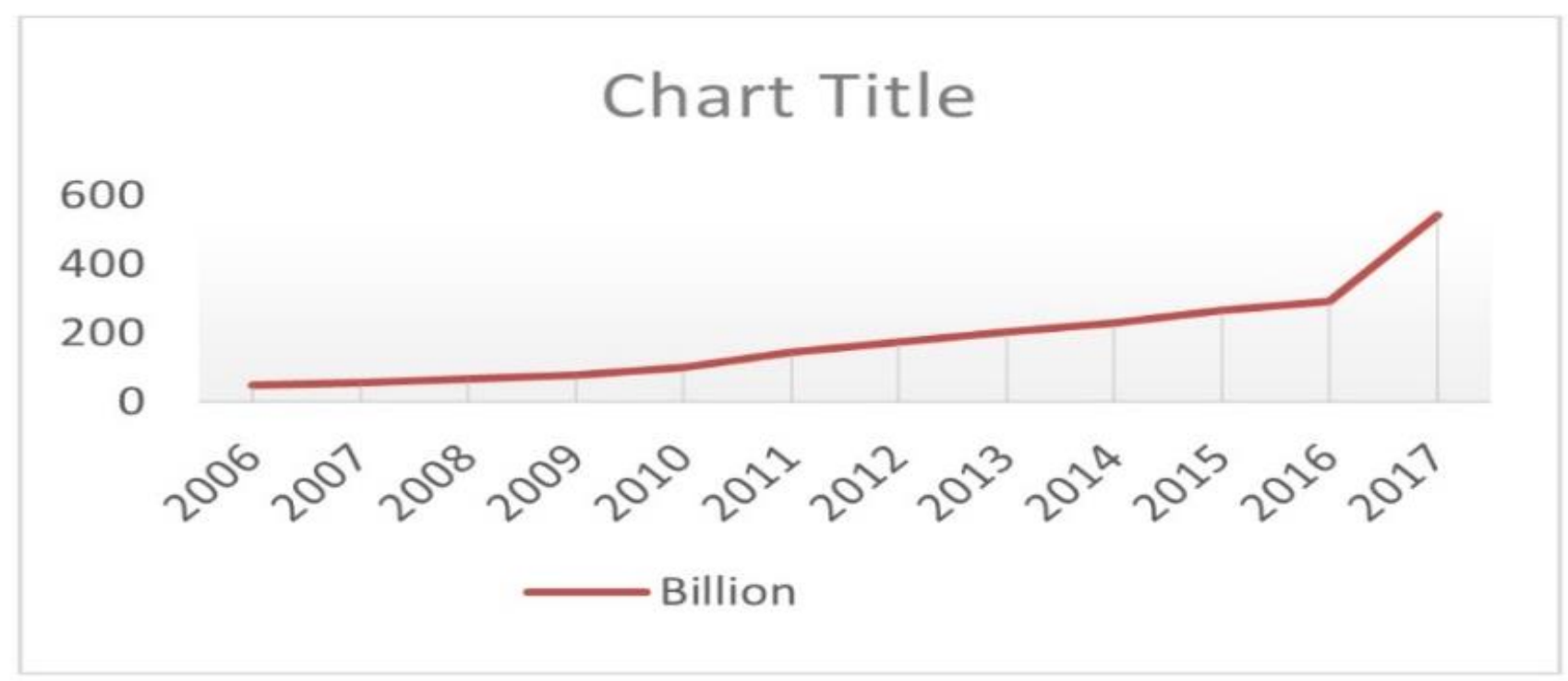

Figure 3. China's Expenditure on Hi-Tech R\&D in Billion Yuan (2006-2018) Source:" http://www.stats.gov.cn/tis//nds/2017/indexeh.htm "

Expenditure on new products and processes also increased significantly in 4 selected categories between 2009 and 2017, namely in: precision machinery; automobiles; railways, ships, and aerospace; and Computers and Communications, as shown in Figure 4.

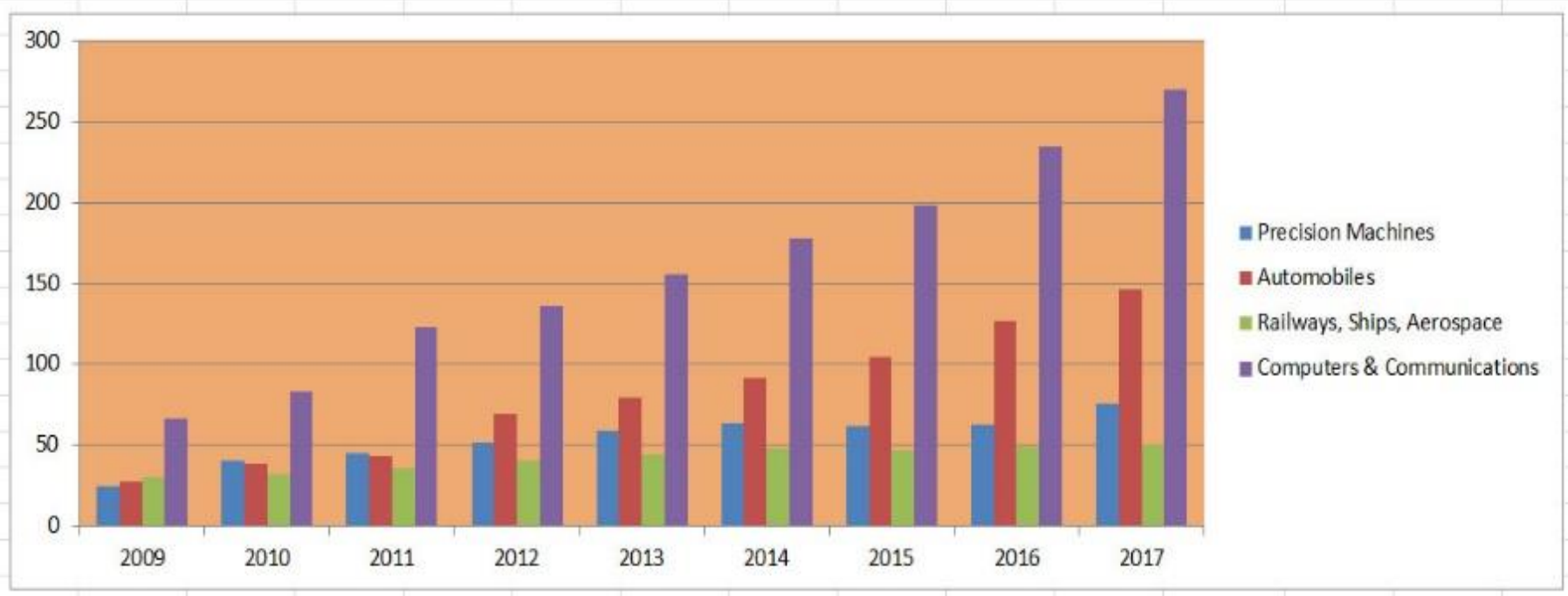

Figure 4. Expenditure in Billions of Yuan on New Products For 4 Selected Categories (20092017) Source: « http://www.stats.gov.cn/tjsj/ndsj/2017/indexeh.htm » 
Table 1 indicates that among many remarkable increase in innovations in 2016 with manufacturing sectors, the sector of: a significantly increased number of published Manufacture of Computers, Communication, academic papers and patent applications in this and other Electronic Equipment showed a sector.

\section{Table 1. Innovation by sector with a process or product innovation.}

\begin{tabular}{|l|l|l|l|}
\hline Sector & $\begin{array}{l}\text { Number of Product or } \\
\text { Process Innovation- } \\
\text { active Enterprises (unit) }\end{array}$ & Product Innovators & $\begin{array}{l}\text { Process } \\
\text { Innovators }\end{array}$ \\
\hline $\begin{array}{l}\text { "Manufacture of Raw Materials and } \\
\text { Chemical Products" }\end{array}$ & 11045 & 28.3 & 30.6 \\
\hline $\begin{array}{l}\text { "Manufacture of Railway, Ship, } \\
\text { Eerospace, and other Transport }\end{array}$ & 2477 & 35.6 & 33.8 \\
\hline $\begin{array}{l}\text { "Manument's" } \\
\text { Communication, and other Electronic } \\
\text { Equipment" }\end{array}$ & 9635 & 47.3 & 44.5 \\
\hline Source: " http://www.stats.gov.cn/tisj/ndsj/2017/indexeh.htm " & & \\
\hline
\end{tabular}

It is equally important to identify the high-tech industrial development zones contributing to the innovation of new products; Shenzhen came first regarding the increasing of the total income from new products. Table 2 illustrates the contribution of each industrial development zone in terms of total income from innovation.

\section{Table 2. Major indicators for the Hi-Tech Industrial Development Zone}

\begin{tabular}{|l|l|l|l|l|}
\hline "Industrial Development Zone" "Number of "Number of Persons & $\begin{array}{l}\text { "Total Income } \\
\text { Enterprises } \\
\text { (unit)" } \\
\text { Engaged (10 000 yuan)" }\end{array}$ & $\begin{array}{l}\text { "Exports } \\
\text { (10 000 yuan)" }\end{array}$ \\
\hline Total & 91093 & 18059323 & 2765593886 & 291460870 \\
\hline Shanghai Zizhu & 115 & 22112 & 5161691 & 349941 \\
\hline Suzhou & 1176 & 225468 & 28125028 & 14714063 \\
\hline Hangzhou & 1950 & 291863 & 43998869 & 3826371 \\
\hline Shenzhen High-tech & 1874 & 485461 & 62085347 & 12947430 \\
\hline Guangzhou & 2868 & 469592 & 60252204 & 7512727 \\
\hline Source: “http://www.stats.gov.cn/tisi/ndsj/2017/indexeh.htm" & & \\
\hline
\end{tabular}


Guangdong, where Shenzhen is located, was the province that ranked first in the expenditure on the development and release of new products, as shown in Table 2. These innovation indicators position Shenzhen at the top of cities playing an outstanding role in increasing innovation capabilities in China. They also highlight the sector of electronics, hardware, and computing as the most innovative sector in China in 2017. Analysis of Chinese companies in the sector of $\mathrm{Hi}$-Tech investing in both internal and external R\&D have shown that the companies that invested more in internal R\&D have applied for more patents than those that invested more in external R\&D. The analysis also showed that internal $R \& D$ was most efficient in foreign companies working in China as compared to private Chinese companies and state-owned enterprises. These results emphasize the importance of having more private $\mathrm{Hi}$-Tech enterprises with a larger role in this sector if China wants to accelerate industrial upgrading according to its ambitious 'Created in China' plan. (Lee et al. 2017).

However, this plan was frowned upon by the US and drew significant criticism, accusing China of subsidizing the Hi-Tech industries, which leads to unfair world competition and adversely affects the interests of major US firms. As for China, it retorted that US S\&T policies also aim to boost technological innovation and amount to subsidizing technology R\&D. Figure 5. presents a comparison between the US and Chinese governments' R\&D spending.

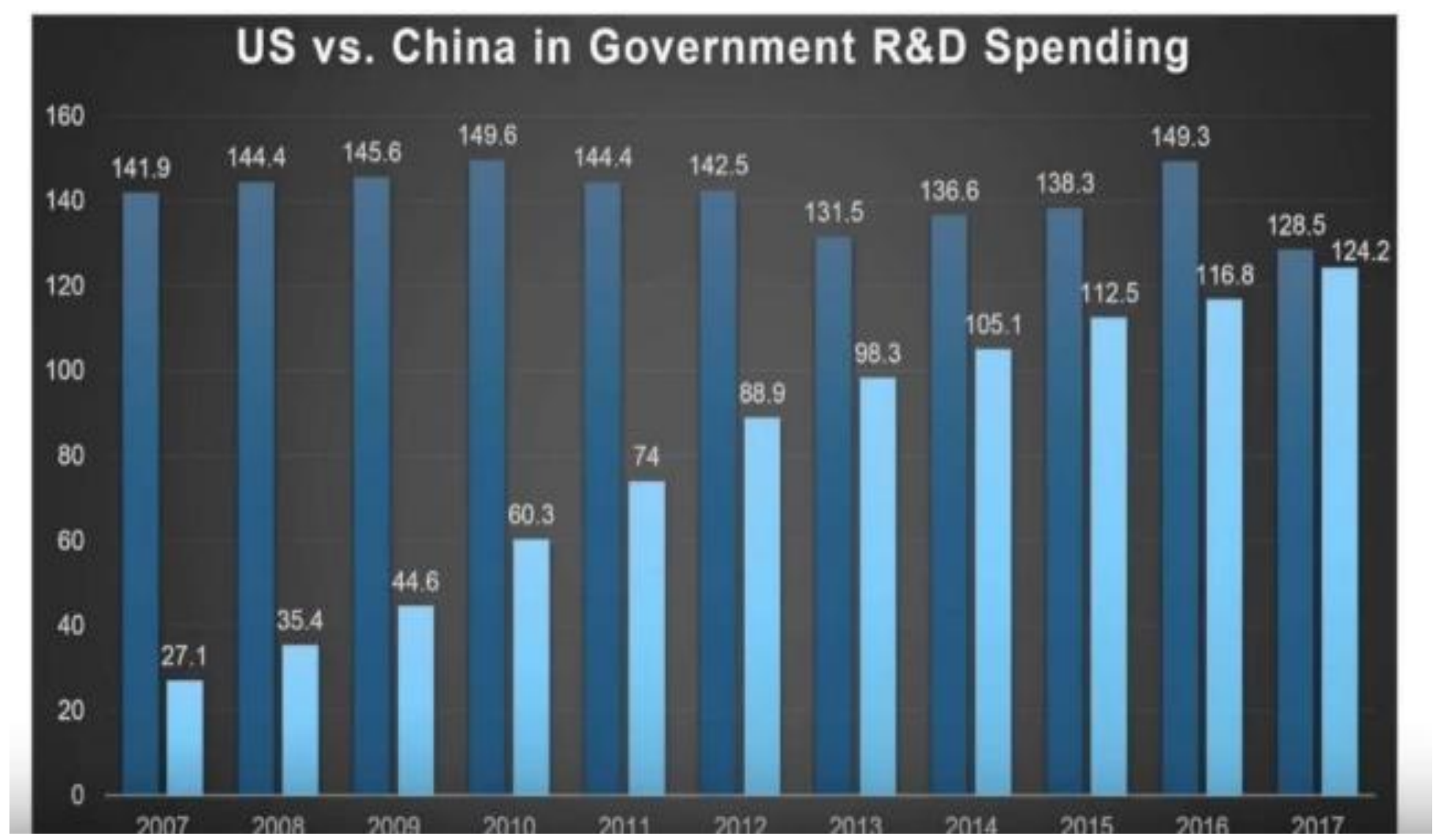

Figure 5: US vs. China in Government R\&D spending. (Lin, 2019)

This friction could also lead to significant changes in the Chinese economy if it persists. As it was indicated by Lewin et al. (2011), massive changes in the global economic and political strength have often been accompanied by conflict, and China is no exception, where regional or global tension could affect unpredictably China's further development, progress, and her ambitious innovation plan, if economic stagnation occurs.

In the following section of this paper, a study was conducted in order to investigate from the 
perspectives of managers and experts in the fields of Hi-Tech industry in China if the rising world trade friction could affect innovation in China, and if so, what exact impacts it will have on innovation from the perspectives of experts in this industry.

\section{Methodology}

It is important to indicate that the scope of this research is limited to the study the perspective of experts in Hi-Tech industry in China. An interview checklist along with a questionnaire were designed and addressed to 140 experts and managers in different Chinese technological industries and companies (with over 100 employees) that are located in four Chinese cities: Beijing, Shenzhen, Shanghai, and Suzhou. The method was based on conducting the techniques of conversational interview via semi-structured interviews, in order to achieve better explanations and clarification of the answers(Lee, 1999; Zhu and Sanderson, 2009; Zhu et al. 2011).

The whole sample covered manufacturing, namely: heavy industrial machines, manufacturing industries, and high-tech equipment, with a size of over 100 workers. Table 3. shows the distribution of the sample by industry and location.

\section{Table 3. Sample's distribution by both location and industry.}

\begin{tabular}{|l|l|l|l|l|l|l|}
\hline Industry & No. & Beijing & Shenzhen & Shanghai & Suzhou & Guanzhou \\
\hline Pharmaceuticals industry & 14 & 4 & 0 & 3 & 2 & 5 \\
\hline Hi Tech & 34 & 20 & 10 & 2 & 2 & 0 \\
\hline Energy industry & 17 & 5 & 2 & 3 & 1 & 6 \\
\hline Auto industry & 11 & 4 & 0 & 3 & 2 & 2 \\
\hline Electrical appliances & 19 & 5 & 3 & 3 & 3 & 5 \\
\hline Construction materials industry & 15 & 5 & 0 & 1 & 3 & 6 \\
\hline Heavy Machine Industry & 13 & 3 & 3 & 2 & 2 & 3 \\
\hline Internet Industry & 17 & 10 & 3 & 2 & 2 & 0 \\
\hline Total & 140 & 56 & 21 & 19 & 17 & 27 \\
\hline
\end{tabular}

The variables included in the study of experts' perspectives were: 1 )-the friction in the global trade scene, 2)-innovation performance in the short term, 3)-innovation performance on the long term, 4)- R\&D investment, 5)- government policy to promote innovation, and 6)- being part of smart manufacturing ecosystem.

The interviewees were asked to give each of those variables an importance rate from 1-5 to indicate the importance intensity or level of importance as follows: 1 for very low importance; 2 for relatively low importance; 3 for moderate importance; 4 for relatively high importance and 5 for very high importance. The questionnaire was pilot tested and reliability was estimated by calculating Cronbach's alpha (Cronbach's alpha $=0.83$ ). By using the Statistical Package for the Social Sciences (SPSS25), the data was then analyzed.

In order to study if there is any significant relationship, according to experts' perspectives, between the ability of companies to innovate and the friction in global trade scene, several points had to be addressed:

First, finding out if there exists any significant relationship between 'friction in the global trade scene' and 'innovation performance in the long term' as well as 'innovation performance in the short term'. We mean by innovation performance 
the creation of new core technology products or processes.

Second, determining if there is any significant relationship between the friction in the global trade scene with 'government policy to promote innovation'?.

Third: determining if this friction in the global scene has a significant relationship with 'increasing R\&D investment on core technology'? Based on the "Pearson correlation" and "regression analysis", the relationships among the variables were studied. Regression analysis is a "statistical procedure for estimating the relationships among variables where the focus, here, is on the relationship between a dependent variable (DV) and one or more independent variables(IV)".(Ommani, 2015), It also helps to develop a better understanding of how the typical value of the DV varied when any one of the IVs is changed, whereas the other IVs are held fixed. A particular use of this analysis is for prediction and forecasting. (Doucouliagos and Stanley, 2013).

The focus of the analysis is on defining which one among the IVs are related to DV, and to explore the nature of these relationships (Frijters and Beattonb, 2012). This method was used previously also to define the relationships between competitive tension and strategic innovation (Gunduz and Semercioz, 2012). It includes many techniques for modeling and analyzing the relationship between DV and one or more IVs.

\section{Discussion}

The results indicated that, according to the experts included in the study, a significant positive correlation between the variables 'friction in the global trade scene' and 'innovation performance in the long-term.' $(r=0.84, P<$ 0.001 ). However, the correlation was negative and weaker between 'innovation performance in the short term' and 'friction in the global trade scene' $(r=-0.47, P<0.001)$.

This could be related to the risk of implementing some new policies and regulations that can hinder the products from competing in other countries. The correlation was significant between 'friction in the global trade scene' and 'clear government policy to enhance endogenous innovation' ( $r=077, P<0.001)$. An interesting result was that 'increasing R\&D investment on core technology' correlates positively with 'friction on the global trade scene' $(r=0.48, \mathrm{P}<0.001)$. For the experts in Hi-Tech industries included in the study, it could be considered a good motivation to depend on domestic resources in order to find creative solutions, processes, or products. Nonetheless, that should also be associated with a clear vision of government policy to enhance and boost endogenous innovation.

From the above, the findings showed that friction in global trade correlates positively with innovation in core technology in the long term but negatively weaker in the short term. They also indicate that innovation in core technology correlates significantly with clear government policy to enhance endogenous innovation.

Regression was applied in Model 1, the DV is endogenous innovation and IVs of period of innovation time, long term and short term of innovation performance, as well as government policy, R\&D expenditure, global trade friction, and being part of a manufacturing ecosystem. Table 4. Shows the results of regression analysis

\section{Table 4. The Results of Regression Analysis}

\begin{tabular}{|l|l|l|l|l|l|l|}
\hline Model & R & R Square & $\begin{array}{l}\text { Adjusted R } \\
\text { Square }\end{array}$ & Std. Error of the Estimate & df1 & Sig \\
\hline 1 & 0.84 & 0.70 & 0.69 & 0.94 & 6 & 0.00 \\
\hline
\end{tabular}


$\mathrm{R}$ represents the correlation, which is high $(0.84)$ adjusted is an unbiased estimator of $r$-square in between predicted and observed values of IV. the population. Standard error 0.94 in our 140 and $R$ square represents the good fit of the model (0.70), the proportion of variance in DV that can be explained by other IVs. The adjusted observations. The results are significant at $\mathrm{df}=6$ and $p<0001$. Figure 6 . shows a normal distribution plot of regression analysis.

$R$ square estimates the population R-square

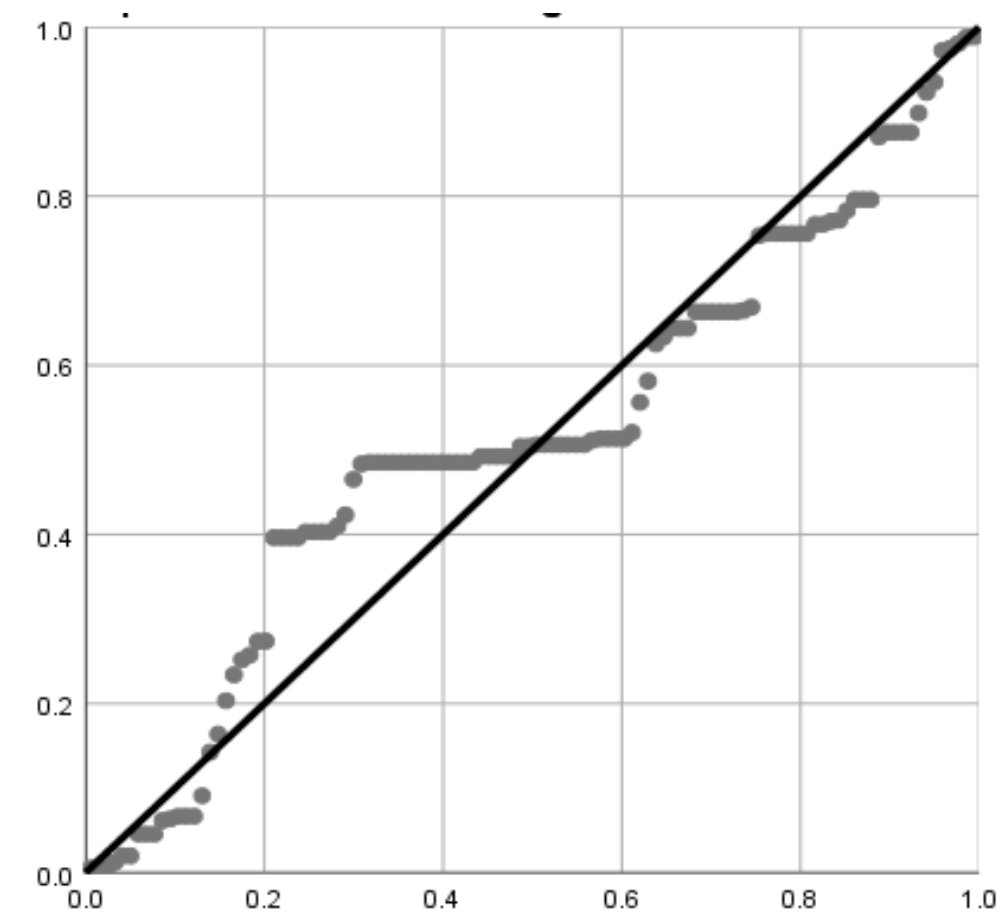

Figure 6: Normal distribution plot of regression analysis of DV and IVs

The findings can be presented in the following equation, where more endogenous could be increased if friction is associated with supporting government policies in the long term, increasing R\&D investment, and smart manufacturing ecosystem.

Constant represents the levels of endogenous innovation if all the other values are zero

ENI: Endogenous Innovation
GTF: Global Trade Friction

RDE: R\&D Investment

IGP: Innovation Government Policies

PIT: Period of Innovation Performance (short or long)

SECO: Being part of a smart manufacturing ecosystem

б: Standard error

$\operatorname{Max}(\mathrm{ENI})=$ Constant $+\operatorname{Max}(\mathrm{GTP})+\operatorname{Max}(\mathrm{RDI})+\mathrm{IGP}+\operatorname{Max}(\mathrm{PIP})+\mathrm{SECO}+\sigma$

In the following, we explore one of the most important sectors in the Hi-Tech industries as deemed by experts to be China's Achilles' heel, that is the semiconductor industry. The current trade disputes and political frictions between the US and China are expected to hit hardest on what may be China's single point of failure,

GJEBA: https://escipub.com/global-journal-of-economics-and-business-administration/ taking into account that almost all major $\mathrm{Hi}$-Tech Chinese products deploy semiconductor chips made in the US or at countries attuned to the US trade policies.

\section{Case Study: China Semiconductors Industry}


The microelectronics industry has been often referred to as today's 'industry of industries' (Dicken, 2003). Semiconductors have emerged with dominating effects in the past four decades, extending their transformative influence into all economy's sectors and many society's aspects (Dicken, 2003). The semiconductor industry involves numerous cutting-edge technologies where every technology applied in the manufacturing process marks the highest level in its field, and the level of semiconductor technology can also, in many ways, demonstrate a country's technological robustness in electronic materials. In China, the semiconductor industry is still a developing sector in its fast-growing High-Tech industries. Ning (2009) indicated that China's domestic semiconductor industry is minor compared to other major semiconductor industries in developed countries.

\subsection{Current State}

Chine has strived in the past three decades on both the government and entrepreneurial levels to build a horizontally integrated semiconductor industry, comprising the stages of design, silicon wafers fabrication as well as chips and packaging manufacturing. However, moving upstream in the supply chain of the semiconductor industry has not yet been successful.

The main reason for China's lagging in the semiconductor industry is that despite the technologically intensive nature of this industry, China has opted to take cheap labor as its chief comparative advantage instead of focusing on technological innovation (Gartner, 2005; Ning 2009). Chinese companies focused on making progress by taking advantage of the low-cost and large scale industrial capacities of China and diversifying their range of products in the low barrier sectors of the semiconductors industry. Table 5 from Ying (2009) captures the status of China's domestic semiconductors industry.

Table 5. China's domestic semiconductor industry's status (Ying, 2009)

\begin{tabular}{|l|l|l|l|}
\hline Stage & Activity & Characteristics & Leading locations \\
\hline Design. & Design of the semiconductor. & $\begin{array}{l}\text { "R\&D intensive - Abundant } \\
\text { high-skilled labor - Strong } \\
\text { IPR environment." }\end{array}$ & $\begin{array}{l}\text { United States, Taiwan China's } \\
\text { participation: Limited. }\end{array}$ \\
\hline $\begin{array}{l}\text { Front-end } \\
\text { Fabrication. }\end{array}$ & $\begin{array}{l}\text { "Construction of } \\
\text { semiconductors on silicon } \\
\text { wafers using highly } \\
\text { sophisticated machinery very } \\
\text { expensive. " }\end{array}$ & $\begin{array}{l}\text { Low-skilled labour - "United States, Korea, Japan, } \\
\text { enhanced } \\
\text { environment. }\end{array}$ & $\begin{array}{l}\text { EU, Taiwan China's } \\
\text { participation: Limited." }\end{array}$ \\
\hline $\begin{array}{l}\text { Back-end testing, } \\
\text { assembly, and } \\
\text { packaging. }\end{array}$ & $\begin{array}{l}\text { "Testing, assembling, and } \\
\text { packaging of semiconductors } \\
\text { for final sale to end customers." }\end{array}$ & $\begin{array}{l}\text {-Less capital intensive } \\
\text { and expensive than front- } \\
\text { end fabrication - more } \\
\text { labour intensive than front- } \\
\text { end fabrication." }\end{array}$ & $\begin{array}{l}\text { Taiwan, the Philippines China's } \\
\text { participation: established and } \\
\text { robust." }\end{array}$ \\
\hline
\end{tabular}

According to a McKinsey and Company Semiconductor report, China's previous attempts to build the industry in the 1990s were not very successful because it failed to develop a nurturing ecosystem for this complex industry. More than 130 fabrication sites were dispersed across 15 provinces, having minimal efforts

GJEBA: https://escipub.com/global-journal-of-economics-and-business-administration/ neither in scale nor in scope of capabilities of fabrication for horizontal and vertical integration (Orr and Thomas, 2014).

In 2016, China produced USD 65 billion of semiconductors and supplied $33 \%$ of the domestic market, which accounts for over than 
Al-Sayed Rafif and Yang Jianhua, GJEBA, 2020; 4:28

$50 \%$ of the international demand for semiconductor chips. It imported USD 227 billion worth of semiconductors, which constitutes its largest import category, almost double the value of its crude oil imports.

This considerable burden on China's trade balance, in addition to political and trade frictions between the US and China regarding tariffs, as well as the increasing US technological exports restrictions on China have all helped convince China of the importance of accelerating its semiconductor industry program, particularly that of the integrated circuits, and pumping-in far greater resources. This also helped in consolidating its determination to re-assume the entrepreneurial role it has successfully played in the past (Link and Scott, 2010). For the forthcoming five years, financial funding from the government will potentially reach USD 179 billion. These investments will be made by the National Industry Investment Fund, and provincial-level authorities. The funds will be used for foreign acquisitions, domestic research and development, tax incentives, loans, and subsidies (Government, 2014). What is apt to mention here, is its latest USD 47 billion semiconductors fund (Yuko, 2018) that is equal in size to the USD 47 billion funds financed by Tsinghua University to spur the growth of an indigenous semiconductor industry (Carsten and Lee, 2015). In the last five years, Tsinghua has bought a number of Chinese companies to bolster its semiconductor manufacturing supply chain (Guo, 2018). This should also be viewed in the context of the ambitious 'Made in China 2025' strategic blueprint that has set a goal for the output of semiconductor industry a target of USD 305 billion by 2030 (State Council, 2015). All these initiatives aim at allowing Chinese manufacturing industries to get $80 \%$ of their semiconductor needs from domestic sources.

\subsection{Challenges}

The past failure of Chinese chip companies was mainly attributed to their over-dependence on state funding and subsidies. This could be potentially repeated unless the new set of policies and funding succeeded in nurturing a solid environment of design, innovation, and technological breakthroughs. This is particularly expected from two domains where China has strong potential: $5 \mathrm{G}$ wireless and Al-focused chips, where China can become a leading provider (Crichton, 2018).

Another problem has to do with costs: despite the very large investment amounts China is pouring into its semiconductor industry, the figures become relatively small when compared to the prohibitive costs of semiconductors R\&D (around 18\% of the turnover) and costs of building state-of-the-art silicon foundries USD 5 billion for a 22 nano-meter wafer (Mims, 2010). In 2017, Intel spent more than USD 13 billion on R\&D expenses, Qualcomm, Broadcom, and Samsung, each spending more than USD 3 billion (IC Insights, 2018). China does not only need to match these huge expenses but also to deliver hard-to-obtain results to justify them.

\subsection{Way Forward}

China's government determination to change the situation regarding its semiconductor industry status is based on a combination of policies and tools that it has successfully adopted in the past in other sectors (e.g. HighSpeed Trains) by adopting the model of the entrepreneurial state. Comprehensibly, when resources are to be integrated and combined in a specific domain, the entrepreneurial state is most capable in this context (Mazzucato, 2018). In order to achieve a synergetic effects and the consolidation of dispersed parties and resources would be undertaken by the government and would have been difficult to be attained otherwise (Link and Scott, 2010). This includes issuing and updating policies, appropriating huge funds, consolidating existing design and fabrication enterprises, acquiring technologies through licensing and acquisitions, and most importantly, strengthening research and development at universities and institutions (Guo 2018). The Chinese strategic vision is based on fostering design, fabrication, testing and packaging semiconductor industries; 
leveraging skills and talents through universities and technology transfers, thus creating a clustering effect that would translate into upgrading indigenous innovation skills and increase demand for raw material suppliers to eventually create an ecosystem that will make china a world-class leader in IC design and fabrication (Government, 2014).

Aiming at leveraging its national semiconductor industry, China issued in 2014 a high level strategy for its new semiconductors policy at the national level. This blueprint sets and ambitious growth strategy that will lead to an annual compound growth rate of 20 percent by 2020 .

The blueprint focused on creating national centers of excellence comprising a small set of industry leaders in each critical sector of the semiconductor industry (namely: design, manufacturing, tools, assembly, packaging and testing) all concentrated in a small number of provinces in order to develop nurturing industry clusters.

The policy adopted has strongly favored mergers and acquisitions to consolidate the growth in scale and scope of these industry leaders. As an example, the state-owned enterprise, Tsinghua Unigroup, acquisitioned in 2013 two of the largest Chinese companies operating on the fabless business model, it acquisitioned "RDA Microelectronics" for about
$\$ 1$ billion and Spreadtrum for about $\$ 1.7$ billion, and integrated them to its own design and fabrication facilities to develop a single entity. The new policy laid special emphasis on consolidating China's assembly, packaging and testing market segments (Orr and Thomas, 2014).

\section{Conclusion,}

This research has explored the perspectives of experts in the Hi-Tech industry regarding the possible effects of friction in the global trade scene on the technological innovation performance in China and whether this will affect the strong determination of China to boost endogenous innovation in domestic companies and sustain economic growth. The research has conducted semi-structured interviews along with questionnaires addressed to a data sample of 140 experts and managers from different technological industries investigate how experts in the field perceive the possible friction influence on the performance of innovation in core technology. The results of the statistical analysis of their answers showed a positive relationship between friction in the global scene has systematic relationships with the long term performance of technological innovation, but a negative and weaker relationship with short term performance, as in the following equation

$\operatorname{Max}(\mathrm{ENI})=$ Constant $+\operatorname{Max}(\mathrm{GTP})+\operatorname{Max}(\mathrm{RDI})+\mathrm{IGP}+\mathrm{Max}(\mathrm{PIP})+\mathrm{SECO}+$

Also, innovation performance in core technology and the clear government policy to enhance endogenous innovation have systematic relationships as well as with the increasing $R \& D$ investment in technological innovation in core technology. Finally, these findings were then applied to an analysis of a case study of the Chinese domestic semiconductor industry in terms of government policies, realities, and challenges. This research has indicated that the challenges of technological innovation in the Chinese semiconductor industry, according to the experts included in the study, will ultimately enhance innovation if it could be associated with a clear vision of government policy to enhance endogenous innovation and increase $R \& D$ investment. The research scope is limited to a specific number of experts in the Hi-Tech industry. Further analysis will be conducted to further enlarge the scope of the research in order to study a possible effect of friction on innovation in the short term in the semiconductor industry in China through the study of Chinese national indicators 


\section{References:}

1. Abrami, R.,Kirby, W. \& McFarlan, F. (2010).China VS the World: Whose Technology Is It? Harvard Review of Book, December 2010.

2. Anil, G., Pande, G.\& Haiyan, W. (2013), The Silk Road Rediscovered, Jossey Bass, Mew Delhi.

3. Barro, R \& Sala-I-Martin, X, (2004) Economic Growth, MIT Press, United States

4. Bhattacharya, M. \& Bloch, H. (2004). Determinants of Innovation. Small Business Economics. Vol. 22 (2): 155-62.

5. Brown, (2017). Made In China 2025 \& Internet Plus: The 4th Industrial Revolution Opportunities for Foreign Invested Enterprises in China , Lehman Brown Insights, July 2017

6. Butollo, F. \& Lüthje, B. (2017). 'Made in China 2025': Intelligent manufacturing and work. In K. Briken, C. Shiona, M. Krzywdzinski, \& A. Marks (Eds), The New Digital workplace: How New Technologies Revolutionise Work (42-61). Houndsmills e.a.: Palgrav

7. Boeing, P., Mueller, E., Sandner, P., (2016). China's R\&D explosion-Analyzing Productivity Effects across Ownership Types and Overtime. Research. Policy. Vol 45 (1), 159-176.

8. Carsten, P. and Lee, Y. (2015). China's Tsinghua Unigroup to Invest $\$ 47$ billion to Build Chip Empire, 6, Nov 16, 2015, www.reuters.com/article/uschina-tsinghua-m-a-idUSKCNOT50DU2015116 Last Accessed. (20-02-2019).

9. Ceccagnoli, M., Forman, Ch., Huang, P; Wu, D. J.. (2012). Cocreation of Value in a Platform Ecosystem: The Case of Enterprise Software, MIS Quarterly, Vol 36(1):263-290.

10. Crichton, D. (2018). The Incredible Multidimensional Chess of Qualcomm vs. Broadcom, March 10, 2018, Techcrunch, Available at https://techcrunch.com/2018/03/10/qualcommvs-broadcom/ Last Accessed. (20-02-2019).

11. Cao, D. (2017). Government Subsidies Boost China's Smart Manufacturing Market. ARC Insights, August 10, 2017. At https://www.arcweb.com/blog/governmentsubsidies-boost-chinas-smart-manufacturingmarket. Last Accessed. (20-02-2019)

12. Dicken, P. and Global S.( 2003) Reshaping the Global Economic Map in the 21st Century. Fourth Edition. ch12 399,

13. Dominguez, G. (2015). 'Made in China 2025' The Next stage of China's Economic Rise? DW, 02.06.2015. http://p.dw.com/p/1FaBt. Last Accessed 1-1-2019

14. Freeman, C. (1996). The Greening of Technology and Models of Innovation. Technological Forecasting and Social Change, Vol(53): 27-39,
15. Freel, M and Robson, P. (2004). Small Firm Innovation, Growth and Performance: Evidence from Scotland and Northern England Int. Small Bus. J., Vol 22 (6) :561-575

16. $\mathrm{Fu}, \mathrm{X}$ and Xiong, $\mathrm{H} .$, (2011). Open Innovation in China: Policies and Practices, Journal of Science and Technology Policy in China, Vol. 2 (3),196218,

17. Fu, X, Pietrobelli, $C$, and Soete, L (2011). The Role of Foreign Technology and Indigenous Innovation in the Emerging Economies: Technological Change and Catching-up in (Eds) World Development. Vol 39(7): 1065-1270 .

18. Frijters, $P$ and Beattonb,, $T$ (2012) The Mystery of the U-shaped Relationship Between Happiness and Age. Journal of Economic Behavior \& Organization Vol. (82): 525- 542

19. Gartner, (2005) Available at https://www.gartner.com/doc/480913/respondchanges-semiconductor-value-chain.

20. Guo, O., (2018) A Crisis Looms over China's Chip Sector, Technology in Asia, https://www.techinasia.com/zte-saga-illustratescrisis-looming-chinas-semiconductor-industry, Last Accessed (20-02-2019)

21. Gunduz, E. and Semercioz, F. (2012). The relation between competitive tension and strategic innovation. Social and Behavioral Sciences. Vol (58): $29-39$

22. Government, (2014) 国家集成电路产业发展推进 纲要, Outlines for Promoting IC development and production (in Chinese), April 24 2014, Available at www.gov.cn/xinwen/201406/24/content_2707360.htm Last Accessed. (2002-2019).

23. Howell, A. (2015). 'Indigenous' innovation with heterogeneous risk and new firm survival in a transitioning Chinese economy. Research Policy, Vol 44(10), 1866-1876.

24. Doucouliagos, H and Stanley, T.D (2013) Publication Selection Bias in Minimum-Wage Research? A Meta-Regression Analysis, British Journal of Industrial Relations, Vol 52(3): 499-520.

25. IMF, (2018). International Monitoring Fund, Washington DC . Available at https://www.imf.org/en/News/Articles/2018/07/25/ na072618-chinas-economic-outlook-in-six-charts. Last Accessed (10-03-2019)

26. IC Insights, (2018). Top 10 Semiconductor R\&D Spenders Increase Outlays $6 \%$ in 2017, IC insights, February 16, 2018, http://www.icinsights.com/news/bulletins/Top-10Semiconductor-RD-Spenders-Increase-Outlays6-In-2017/, Last Accessed (10-03-2019)

27. Lee, W. (1999). Using Qualitative Methods in Organizational Research. Thousand Oaks, CA: GJEBA: https://escipub.com/global-journal-of-economics-and-business-administration/ 15 
Sage.

28. Lee, Sang-Ho and Chen, Zhao ., Xu, Wei (2017): R\&D Efficiency in High-Tech Firms in China. Forthcoming in: Asian Economic Papers , Vol. 16, (October 2017).

29. Lewin, A. Y. Kenney,M., and Murmann, J.P. (2016). China's Innovation Challenge: Overcoming the Middle-Income Trap, Cambridge University Press, 2016.

30. Lin, Y, (2019). China's IP Development and R\&D Investment, Made in China 2025 Conference, Asian Society, January 2019.

31. Link, N. and Scott, T. (2010). Government as Entrepreneur: Evaluating the Commercialization Success of SBIR projects. Research Policy, Vol (39):589-601.

32. Litan, R.E., Wycoff, A. W., Fealing, K. H. (2014). Capturing Change in Science, Technology, and Innovation: Improving Indicators to Inform Policy. National Academy of Sciences, USA

33. Liu, Y, Songling, X., Ruonai, F. (2014). The Alibaba model: Growing by Unleashing Grassroots Entrepreneurship, Citic.

34. Kline, S. J. \& Rosenberg, N. (1986). An overview of innovation. In: Landau, R. \& N. Rosenberg, N. (Ed.). The Positive Sum Strategy: Harnessing Technology for Economic Growth. Washington: National Academy Press,. 275-304.

35. MAPI, (2014). Manufacturers Alliance for Productivity and Innovation Report, China has Dominant Share of World Manufacturing. Available at https://www.mapi.net/blog/2014/01/china-hasdominant-share-world-manufacturing. Last Accessed. (20-04-2018)

36. Mazzucato, M. (2018). The Entrepreneurial State, Penguin, UK Available at. https://www.penguin.co.uk/books/305469/theentrepreneurial-state/9780141986104.html

37. McKinsey, (2015). The China Effect on Global Innovation, McKinsey Global Institute, October 2015 Available at http://mckinseychina.com/thechina-effect-on-global-innovation/. Last Accessed. (20-02-2019).

38. Mims, C. (2010). The High Cost of Upholding Moore's Law, MIT Technology Review, April 20, 2010

https://www.technologyreview.com/s/418576/thehigh-cost-of-upholding-moores-law/, Last Accessed. (20-02-2019).

39. Ning, L. (2009). China's Rise in the World IT Industry. OECD Reviews of Innovation Policy China, Synthesis Report.

40. Orr, G. and Thomas, C. (2014) Semiconductors in China: Brave new world or same old story?
McKinsey and Company, April August Available at https://www.mckinsey.com/industries/semiconduc tors/our-insights/semiconductors-in-china-bravenew-world-or-same-old-story, Last Accessed. (2002-2019).

41. Ommani, A. (2015). Regression Analysis of Innovation Management in Processing

42. and Complementary Industries of Livestock Products. International Journal of Agricultural Management and Development, 5(3): 179-185.

43. OCED, 2015 at http://www.compareyourcountry.org/science-andtechnology.Last Accessed. (20-02-2019).

44. State Council, (2015) 中国制造 2025 (Made in China 2025 - in Chinese) available at available http://www.miit.gov.cn/n973401/n1234620/n1234 622/c4409653/content.html, accessed Nov 27, 2018. Last accessed (20-02-2019)

45. State Council, (2013), The Belt And Road Initiative, available at http://english.gov.cn/beltAndRoad/. Last accessed (20-02-2019)

46. State Council, (2017). State Council of the People's Republic of China, A Next Generation Artificial Intelligence Development Plan, No. 35. Original Document: at http://www.gov.cn/zhengce/content/201707/20/content_5211996.htm, English Translation: available at https://www.newamerica.org/cybersecurityinitiative/blog/chinas-plan-lead-ai-purposeprospects-and-problems/. Last Accessed. (20-022019).

47. Schwab, K (2016). The Fourth Industrial Revolution, The World Economic Forum.

48. SIPO, (2017). Available at http://www.sipo.gov.cn, Responsibilities of the State Intellectual Property Office of the People's Republic of China (SIPO), 2007.0. Last Accessed. (20-02-2019).

49. Romer, P. (1990). Endogenous Technological Change, University of Chicago, Available at http://120.52.51.17/pages.stern.nyu.edu/ promer /Endogenous.pdf

50. Tong S and Wan, J. (2017). China's Economy in Transformation under the New Normal. Al Series on East Asia. World Scientist Publishing. Singapore

51. Wübbeke, J., Meissner, M., Zenglein, M.J., Ives, J., Conrad, B. (2016). 'Made in China 2025', The Making of a High-Tech Superpower and Consequences for Industrial Countries, Merics papers on China, December. 2016. At.https://www.merics.org/fileadmin/user_upload/ downloads/MPOC/MPOC_Made_in_China_2025 /MPOC_No.2_MadeinChina_2025.pdf. Last Accessed. (20-02-2019)

GJEBA: https://escipub.com/global-journal-of-economics-and-business-administration/ 
52. Yinug, F.(2019). Challenges to Foreign Investment in High-Tech Semiconductor Production in China. United States International Trade Commission Journal of International Commerce and Economics. May 2009

53. Yip, G and McKern, B. (2014) Innovation in Emerging Markets - the Case of China, International Journal of Emerging Markets. Vo 19( No.1)

54. Yuko, 2018. China Plans $\$ 47$ Billion Fund to Boost Its Semiconductor Industry, The Wall Street Journal, https://www.wsj.com/articles/chinaplans-47-billion-fund-to-boost-its-semiconductorindustry-1525434907, last accessed (20-022019.)

55. Zhang, X., Rudd, K., Cai, J., Lon, G., Chen, H., Foster, G., Han, J., Li, M., (2016). China's Innovation Ecosystem, White Paper, World Economic Forum, August 2016, At
http://www3.weforum.org/docs/WEF GAC On C hina_Innovation_WhitePaper_2016.pdfLast accessed (20-02-2019.)

56. Zhou W., Lee YF.L., Hyman M.R. (2017). How China's "Double-Eleven" Day Challenges Confucianism: In: Stieler M. (Eds) Creating Marketing Magic and Innovative Future Marketing Trends. Developments in Marketing Science: Proceedings of the Academy of Marketing Science. Springer, Cham

57. Zhu, Y., Wittmann, X., and Peng, M.W. (2012). Institution-based barriers to innovation in SMEs in China. Asia Pacific Journal of Management Vol.29 (4):1131-1142.

58. Zhu, Y., and Sanderson, J. W. (2009). The Key Obstacles and Countermeasure against Development of Innovative SMEs in China. China Soft Science, Vol(9): 23-31.

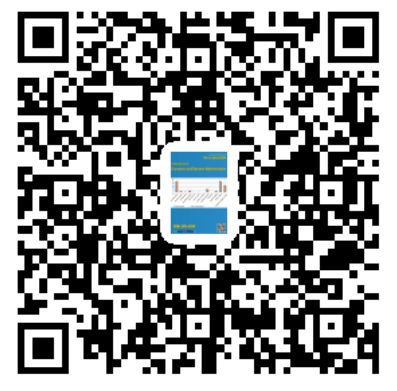

